\title{
SELECTED ISSUES OF JUVENILE DELINQUENCY PROCEEDINGS
}

\begin{abstract}
Aвstract. Rajewska de Mezer Joanna, Selected issues of juvenile delinquency proceedings [Wybrane problemy postępowania wobec nieletnich popełniających czyny karalne ]. Studia Edukacyjne nr 48, 2018, Poznań 2018, pp. 229-248. Adam Mickiewicz University Press. ISSN 1233-6688. DOI: 10.14746/ se.2018.48.15
\end{abstract}

This paper discusses selected issues of juvenile delinquency proceedings. It points the reader's attention to the difference in the approach towards a juvenile offender. This different approach consists in shaping the way the state reacts to them breaking a legal norm and directing it towards resocializing education. It underlines the specific characteristics of the interactions' subject - a juvenile whose identity and social attitudes are in the making. These features justify the fact that educational and reformatory measures based on the law on juvenile delinquency proceedings are applied in their case, rather than the punitive ones defined in the Penal Code. The paper analyses selected topics related to executing specific (educational or reformatory) measures that spark controversy among the entities that take up educational, activating and aid-related actions.

Key words: juvenile, juvenile offender, juvenile delinquency proceeding, educational measure, corrective measure, rehabilitation

It has been our dream and the desire of many previous generations to live a life with a sense of security and stability of existence conditions in a society that adheres to some established rules of functioning. The security and stability would manifest themselves by social and legal norms that protect personal goods of every human being obeyed.

However, since time immemorial, as proved by the facts described in ancient works, philosophers' deliberations in the Middle Ages or eras of human existence closer to contemporary times, the man has been using their free will and taking the decision to commit acts that break the rules determined and in force in a given community. By committing a criminal act, they would face 
the society's reaction in the form of punishment. Depending on the period of history when the offence occurred, legal system binding in a given society, social layer or class the offender originated from, the punishment inflicted on them would have a different form, intensity and character.

At first, punishment was supposed to do justice and, according to the theories of absolute penalty, it provided revenge on the offender for the punishable act they had committed. The main aim of punishment was to severely retaliate on the offender who was perceived from the angle of the act they committed against the binding law. At that time, the possibility of undergoing a change, rehabilitating the offender, considering their age, motivation or objective etc. at the moment the act was committed were not taken into account. Punishment and its objective were perceived in that way in ancient legislations (for example, in the Code of Hammurabi or the Greek laws of Solon and Drakon). G.W. Hegel, the author of modern idealism, claimed that punishment is supposed to make the idea of justice reality, and not to serve social objectives. ${ }^{1}$

It was only later that theories called relative, or utilitarian, appeared; they included (general and individual) prevention among the objectives of punishment. According to them, when inflicting punishment on the offender, they have to be reviewed from the angle of their chances for rehabilitation and change, and the punishment itself has to serve to protect the society by preventing crimes from being committed in the future. Focused on an offender's future, "(...) in order for crimes not to be committed", relative theories are called prospective. ${ }^{2}$

Elements of both punishment theories quoted above are included in the so-called mixed theories. According to them, individual and general prevention, as well as fair retribution are equally important. Also, individual, and general and preventive objectives complement one another, because preventing crime is a result of both the influence of punishment on a specific offender, and on the entire society. ${ }^{3}$

When considering the topic of the purpose of using punishment, its preventive character aimed at protecting the society, and at the same time the change in the functioning of an individual who acts against the legal norm in force, we pose questions on the effectiveness of using sanctions and their effective influence on the attitude of the punished person. At present, the process of punishment is based on the assumptions of the mixed theories of punishment. It includes fair retribution for breaking a norm defined by the socie-

${ }^{1}$ M. Kuć, Prawne podstawy resocjalizacji, Warszawa 2011, p. 38.

2 L. Gardocki, Prawo karne, Warszawa 2017, p. 165.

3 Zob. Ibidem, p. 165 i n.; B. Stańdo-Kawecka, Prawne podstawy resocjalizacji, Kraków 2000, p. 15-21; M. Kuć, Prawne podstawy resocjalizacji, p. 37-41. 
ty and, importantly, it underlines its preventive objectives. This is reflected in the regulations of both substantive criminal law and executive criminal law. ${ }^{4}$

However, taking into account the subject of this paper, it is important to underline that at present offenders are not always brought to justice, even though they committed an act of criminal nature, acted against the law breaking a legal norm in a culpable way and the social harmfulness of their act was qualified as higher than negligible.

Apart from situations excluding the criminality of the act defined by law (for example, the unlawfulness of the act - the so-called contratypes, or no culpability of the perpetrator), in principle no punishment as understood in criminal law is inflicted on a perpetrator who was under 17 at the moment of committing an unlawful act. ${ }^{5}$

Criminal acts are committed by perpetrators of different ages. Norms of criminal law are broken by both fully sane adults of full capacity and by underage people of under 18, sometimes even children whose characteristic feature is the lack of an adequate perception of reality and who are not always fully aware of the meaning of their act.

According to the regulations of the Polish penal law, punishment can be inflicted on a person of under 17 (age at the moment of committing an unlawful act) under exceptional circumstances, once conditions established in the law have been fulfilled. Penal Code regulations can only be applied to a juvenile of under 17 who committed an unlawful act after turning 15 when they perpetrated one of the unlawful acts enumerated in the article $10 \S 2$ of prohibited acts ${ }^{6}$ and if it is justified by case circumstances, stage of the perpetrator's development, their characteristics and personal situation. Following the article $10 \S 2$, it is possible to apply punishment when conditions are met as far as the type of the act committed, perpetrator's characteristics and case circumstances are concerned. ${ }^{7}$ However, even in case of a juvenile of less than 17 years of age committing a punishable act that allows to apply Penal Code regulations against them, the adjudicated punishment cannot exceed

${ }^{4}$ In material penal law, punishment is a fair retribution for the crime committed and condemnation of a perpetrator's unlawful act (after: I. Andrejew, L. Gardocki, K. Buchała, A. Zoll, J. Warylewski etc.). On the other hand, according to the regulations of the executive penal law, punishment is used in order to make the perpetrator " $(. .$.$) be willing to cooperate in shaping$ their socially desired attitudes, in particular their sense of responsibility and need to obey the legal order and thus to refrain from committing a crime again" (art. 67 ustawy z 6 czerwca 1997 Kodeks karny wykonawczy (DzU z 2017, poz. 665 ze zm.)).

${ }^{5}$ Art. 10 §1 ustawy z 6 czerwca 1997 Kodeks karny (DzU z 2016, poz. 1137 ze zm.).

${ }^{6}$ According to the article $10 \$ 2$, these are the prohibited acts defined in the article 134, article $148 \S 1,2$ or 3 , article $156 \S 1$ or 3, article $163 \S 1$ or 3, article 166 , article $173 \S 1$ or 3, article $197 \S 3$ or 4, article $223 \S 2$, article $252 \S 1$ or 2 and article 280 of the Penal Code law of 6 June 1997 (DzU z 2016, poz. 1137 ze zm.).

${ }^{7}$ L. Gardocki, Prawo karne, p. 66. 
two thirds of the upper threshold of the threat described by law for the crime attributed to the perpetrator. Moreover, the court can apply extraordinary mitigation of punishment in case of such a juvenile. ${ }^{8}$ According to the Polish law, a perpetrator of less than 15 years of age does not hold criminal responsibility for an act bearing the characteristics of a crime. Regulations provided for in the law on juvenile delinquency proceedings are applied in their case.

Courts adjudicating in cases where a punishable act ${ }^{9}$ was committed by a juvenile who had turned 17 years old often seek the option to apply the disposition included in the article $10 \S 4$ of the Penal Code that allows to adjudicate a more relative means of influence in the form of educational or corrective measures, based on the previously-mentioned law on juvenile delinquency proceedings. The above-mentioned article $10 \$ 4$ of the Penal Code law contains a solution that allows to refrain from punishing a juvenile who was already 17 at the moment of committing a punishable act (offence), but who is not of legal age yet if it is justified by case circumstances, stage of the perpetrator's development, their characteristics and personal situation. In such an offender's case, the court applies educational, treatment or corrective means as provided for the juvenile. ${ }^{10}$

The above shows that the approach towards a juvenile offender is of individual character in our country's penal law, and different from the approach towards an adult offender. Regulations that differentiate formal approaches towards juvenile perpetrators who break the legal norm have already been used in legal acts in the past.

Already in the past, the society was aware of the fact that juvenile perpetrators were treated differently. The need to match the objective of protecting public order with the departure from classic penal reactions towards acts of the juvenile has been "(...) making the issue of treating the juvenile a particularly complex one".${ }^{11}$ The awareness that it was necessary to differentiate the way juvenile and adult offenders were treated was already present in ancient times.

${ }^{8}$ R.G. Hałas, Podmiot przestępstwa, [w:] Prawo karne, Eds. A. Grześkowiak, K. Wiak, F. Ciepły, M. Gałązka, R.G. Hałas, S. Hypś, D. Szeleszczuk, Warszawa 2017, p. 103.

${ }_{9}^{9}$ Ustawa z 26 października o postępowaniu w sprawach nieletnich (DzU z 2016, poz. 1654 ze zm.) nie posługuje się pojęciem „przestępstwa” popełnionego przez osobę nieletnią, zastępując je pojęciem "czynu karalnego" i zamieszczając w art. 1 §2 pkt 2 ustawy jego definicję legalną, zgodnie z którą przez czyn karalny rozumie się „(...) czyn zabroniony przez ustawę jako: a) przestępstwo lub przestępstwo skarbowe albo b) wykroczenie określone w art. 50a, art. 51, art. 69, art. 74, art. 76, art. 85, art. 87, art. 119, art. 122, art. 124, art. 133 lub art. 143 Kodeksu wykroczeń.

${ }_{10}$ Art. $10 \S 4$ ustawy z 6 czerwca 1997, Kodeks karny (DzU z 2016, poz. 1137 ze zm.).

${ }_{11}$ T. Bojarski, Podstawowe założenia traktowania nieletnich w świetle ustawy o postępowaniu w sprawach nieletnich oraz aktualnych potrzeb, [w:] Teoretyczne i praktyczne problemy stosowania ustawy o postępowaniu w sprawach nieletnich, Eds. T. Bojarski, E. Skrętowicz, Lublin 2001, p. 14 and n. 
The Roman law distinguished: children - infantes (up to 7 years old), the immature ones - impuberes infantia maiores (girls aged 7-12 and boys aged 7-14), the mature ones - puberes viginti guiuque anni minores (girls aged 12-25 and boys aged 14-25) and full adults (people aged over 25). Children did not bear criminal liability for a crime committed; Impuberes were held responsible only when the stage of their mental development made them capable of understanding the meaning of their act (thus the punishment inflicted on them would have a milder form); whereas Minores in principle were held responsible like adults. The Roman model of juvenile delinquency proceedings was widespread in medieval Europe and influenced the way legal regulations were shaped in various states up till the $19^{\text {th }}$ century. ${ }^{12}$

The French model of juvenile delinquency proceedings based on the 1791 Penal Code was the first to introduce educational means in the form of parental supervision and placement in a youth detention centre next to punishment. They were applied to juvenile offenders under 16 who did not act with discretion. On the other hand, in case of a juvenile who acted with discretion, punishment used to be mitigated, with the death penalty abolished completely.

In the Austrian model, adopted by the Polish Penal Code for the Kingdom of Poland in 1818 based on Josephine, ${ }^{13}$ a division of the juvenile into three age groups was established: underage who are irresponsible in absolute terms, underage who are responsible to a limited degree and those who are responsible in absolute terms. ${ }^{14}$ The above models influenced the way laws on juvenile delinquency proceedings have been shaped around the world.

A different formal approach to a juvenile who is at conflict with a legal norm is due to the specific characteristics of the subject of interactions itself that were noticed and taken into account in legal regulations in various periods of history. When analysing the rules of juvenile delinquency proceedings, what is pointed to is the unfinished process of them shaping in the course of socialization, building a sense of responsibility for their actions, limited skills at evaluating the situation, drawing conclusions and remaining under the demoralizing influence of significant adults.

A juvenile at puberty still develops on the mental level; their growth in this respect has not finished yet. According to J. Piaget, a child's knowledge built as a result of interactions between the child and their environment is not

12 P. Górecki, Postępowanie poprawcze w sprawach nieletnich, Sopot 1998, p. 16-17.

${ }^{13}$ Josephine (German Josephina) - General Code on crimes and their punishment (Allgemeines Gesetz über Verbrechen und derselben Bestrafung) is a penal code enacted by emperor Joseph II (thus it is colloquially names after the emperor), in effect since 1787 in Habsburg Monarchy countriep. The code was one of the sta ges of development of the modern penal law.

${ }^{14}$ P. Górecki, Postępowanie poprawcze, p. 18 
organised in an innate way or provided directly by the environment where they function. This knowledge is built as a result of the child's active investigation of objects and then notions. On the other hand, the development of intelligence is a process of precise and complex adaptation to the environment, assimilation and accommodation..$^{15}$ According to Piaget's theory of cognitive development, mental development is complete after an individual has reached the stage of formal operations. ${ }^{16}$ It is only at this stage that the integration of previously gained experience into a sort of database that serves mental processes of a higher level (the skills of inductive and deductive thinking that constitute abstract thinking) takes place. Piaget pointed to the fact that not all individuals develop mentally up to the formal operational stage. A juvenile at the earlier preoperational stage is not yet capable of considering a situation from the point of view of another person, which is typical for the egocentrism characteristic of this stage of development. The quoted author states that at the initial stage of puberty a juvenile's thinking process is influenced by thinking based on concrete terms. When the so-called formal thinking develops in a child's cognitive structures (at the age of 15 and up), it allows them to predict the results of their actions and, importantly, to be able to theorize on what may happen. A child becomes thus equipped with the competence to hypothesize on possible scenarios. This results in their ability to predict the effects of their actions or consequences of hypothetical events that may happen in the future. According to Piaget, passing from concrete operations to the full formal operational stage takes place at the age of between 11 and 14 . According to cognitive psychologists, the remains of the egocentric approach to reality (characteristic of the preoperational stage) at the formal operational stage lead to many implications in an individual's behaviour, perception of the reality around them and their attitude towards it. This state of affairs consequently leads to the development of self-awareness and deductive thinking, a sense of constant control consisting in a conviction that our actions are continuously controlled and evaluated by the environment, strongly subjective conviction about one's uniqueness (perceiving one's thoughts and feelings as unique), conviction about one's immortality and prime mover which results in adopting risky behaviours. ${ }^{17}$

${ }^{15}$ H.R. Schaffer, Psychologia dziecka, Warszawa 2009, p. 188 and n.

16 Piaget's stages of cognitive development: sensimotor stage (birth to 2 years), preoperational stage (2 to 7 years), concrete operational stage (7 to 11 years), formal operational stage (11 and up) za: Ibidem, p. 190.

17 Szerzej J. Piaget, Studia z psychologii dziecka, Warszawa 1966; J. Piaget, B. Inhelder, Psychologia dziecka, Wrocław 1993; H. Bee, Psychologia rozwoju człowieka, Poznań 2004; J. Strelau, D. Doliński (Eds.), Psychologia: podręcznik akademicki, t. 2, Gdańsk 2008; H.R. Schaffer, Psychologia dziecka. 
The above discussion of the stages of human cognitive development in the period before reaching adulthood justifies a different, more relative formal approach to a juvenile offender, as they are individuals who do not have full legal capacity, whose self-awareness is still in the process of being shaped, who are only just building their ability to draw conclusions on hypothetical results of their actions and developing deductive thinking skills.

The law on juvenile delinquency proceedings that is in effect in Poland provides an answer to the need to shape the way a juvenile delinquent is dealt with in a slightly different form due to the specific characteristics of the subject. It suggests viewing them from the angle of educational and resocialization activities instead of sanctions or punitive measures that result from applying punishment based on the rules of criminal proceedings.

The aim of the law is to strive for preventing juvenile demoralization and criminality, create appropriate conditions for those juveniles who are at conflict with the law or rules of social coexistence so that they can return to normal life, and foster the protective and educational function of the family, as well as their sense of responsibility for bringing up the underage to become society members who are aware of their duties. ${ }^{18}$

If a juvenile delinquent is not subject to penal law regulations due to their age or other excluding factors, regulations of the above-mentioned law on juvenile delinquency proceedings are applied. ${ }^{19}$ As mentioned previously, under such circumstances a prohibited act committed by a juvenile ${ }^{20}$ is not called a crime, and it is named a punishable act in line with the law. The law does not provide for inflicting punishment on a juvenile delinquent, but it allows for applying measures of educational and corrective character regulated in this act. The law-maker also provided for using a treatment and educational measure towards a juvenile who was diagnosed with a mental disorder, mental illness, another mental malfunction or addiction to other substances with the aim of intoxicating oneself. ${ }^{21}$ With a holistic approach to formal reactions to a juvenile's acts bearing the characteristics of demoralization, the regulations of the law on juvenile delinquency proceedings have been shaped

${ }^{18}$ Preambuła do ustawy z 26 października o postępowaniu w sprawach nieletnich (DzU z 2016, poz. 1654 ze zm.).

${ }^{19}$ Ustawa z 26 października o postępowaniu w sprawach nieletnich (DzU z 2016, poz. 1654 ze zm.).

${ }^{20}$ In accordance with the article $1 \S 2$ point 1 of the law on juvenile delinquency proceedings, a juvenile is: 1) A person under 18 if they undergo proceedings with regard to preventing and fighting demoralization, 2) A person who committed a punishable act after turning 13 but who has not turned 17 yet, and who is a subject of proceedings for misdeed (bearing the characteristics of a crime), 3) A person who is submitted to educational and corrective measures as adjudicated, yet no longer than till they turn 21.

${ }^{21}$ L. Gardocki, Prawo karne, p. 68. 
throughout many years of discourse among supporters of various solutions as far as dealing with juvenile delinquents is concerned.

As early as in the interwar period, the issue of whether punishment, or a sanction provided for by law, which includes an element of retribution for their culpable deed at variance with the binding law, should be inflicted on a juvenile offender was controversial. Taking into account their young age, physical immaturity, often mental dysregulation, and the fact that their identity, self-awareness and sense of responsibility were still developing, they might need to be treated differently, applying measures that lack the characteristics of sanctions, and that are directed at educating and resocializing them.

With regard to the underage, the literature mentions three models of justice whose elements are present in legal systems of juvenile delinquency proceedings: juridical (retribution) model, educational (resocialization, tutelary) model and restorative justice model. ${ }^{22}$

According to the juridical model, a juvenile who committed a punishable act should be held responsible by having penal measures applied against them (penal notes appear at this point). As early as in the interwar period, the majority of criminal lawyers who commented on the Penal Code law of 1932 were convinced of the retaliatory, sanction-like character of corrective measures used towards a juvenile. ${ }^{23}$ At present, L.Gardocki is, for example, among the supporters of using the elements of that model; he suggested that the bottom threshold of juvenile responsibility for their misdeed should be lowered, ${ }^{24}$ which was reflected in the regulations of the Penal Code of 1997.

According to the claims of other experts on the interwar period, a youth detention centre was perceived as intermediary between punishment and educational measures, thus becoming a "quasi-punishment". ${ }^{25}$

In opposition to the juridical model, the educational model underlines it that it is necessary to take the mental and social needs of the juvenile into account, as well as the fact of their identity still being under construction, in the process of mental and physical growth characteristic of this period of their life. ${ }^{26}$ Its characteristic element is about influencing the juvenile with measures that are aimed at educating and resocializing, and not punishing them.

The third model that science has created is called the restorative justice model. This one, in turn, is aimed at attempting to compensate for the damage

${ }^{22}$ K. Gromek, Wprowadzenie do ustawy o postępowaniu w sprawach nieletnich po nowelizacji $z$ dnia 15 września 2000 r., Warszawa 2001, p. X.

${ }^{23}$ L. Peiper, Komentarz do Kodeksu Karnego, Kraków 1932, p. 187-192; J. Makarewicz, Kodeks karny z komentarzem, Lwów 1932, p. 149.

${ }^{24}$ L. Gardocki, Czy karać nieletnich? Palestra, 1994, 38/11 (443), p. 74-76.

${ }^{25}$ W. Wolter, Zarys systemu prawa karnego, t. 2, Kraków 1933, p. 152.

${ }^{26}$ A. Grześkowiak, Postępowanie w sprawach nieletnich (polskie prawo nieletnich), Toruń 1986, p. 44. 
and harm caused by a juvenile's act. Restorative justice is defined as a process where people linked to a specific crime committed take part and care about preventing its present and future consequences. ${ }^{27}$ The paradigm of restorative justice is based on three main rules: the party aggrieved by the misdeed is entitled to compensation, the criminal offender undertakes to be held responsible for their deed, and both parties, accompanied by other members of the local community and an intermediary, try to work out a satisfying solution that becomes an agreement. Mediation is one of the basic forms of restorative justice; in mediation "(...) both the offender and the culprit of the crime have an opportunity to make an adequate self-evaluation, enhance autonomy and independence, take responsibility for their behaviour, respect social norms $(\ldots)^{\prime \prime} .^{28}$ The parties have to integrate for the duration of the mediation proceedings, so that it is possible to start effective cooperation for working out a solution that will be satisfying for both parties. ${ }^{29}$

In contemporary legal systems, there are no pure examples of the abovementioned models. The systems combine elements of different models, which leads to the creation of indirect forms. The law on juvenile delinquency proceedings in effect in Poland is based on elements of the educational and tutelary model focused on protecting and rehabilitating a juvenile at risk. ${ }^{30}$ However, following an analysis of this legal act, elements characteristic of the other two models mentioned can also be noticed in it.

The aim of the law is to counteract juvenile demoralization and delinquency, and create conditions for returning to a normal life for those underage who are at conflict with law or rules of social coexistence. Also, importantly, its objective is to strengthen family's tutelary and educational function and sense of responsibility for bringing up the juvenile to become society members who are aware of their duties. The law provides for a dichotomic division of measures into educational ${ }^{31}$ and corrective, i.e. consisting in adjudicating a stay at a youth detention centre for the underage.

${ }^{27}$ B.D. Meier, Sprawiedliwość naprawcza - zarys koncepcji, [in:] Mediacja. Nieletni przestępcy i ich ofiary, Eds. B. Czarnecka-Dzialuk, D. Wókcik, Warszawa 1999, p. 39, cyt za: A. Lewicka-Zelent, Wspólna przestrzeń dla resocjalizacji inkluzyjnej i mediacji, Probacja, 2016, IV, p. 26.

${ }^{28}$ Ibidem, p. 27.

${ }^{29}$ Ibidem, p. 26.

${ }^{30}$ M.Kuć, Prawne podstawy resocjalizacji, p. 140-141.

${ }^{31}$ Measures of educational character include (art. 6 upn)

1. Reprimanding;

2. Obligation to act in a specific way, especially to make up for the damage caused, carry out specific work or services for the injured party or local community, apologize to the injured party, take up studiem or work, participate in adequate classes of educational, therapeutic or training character, refrain from staying in some specific environments or places, or stop using alcohol or another substance in order to induce intoxication;

3. Appointing a parent or guardian for responsible supervision; 
Practice shows that in many cases the initial reaction of the family and juvenile court towards the acts reflecting a juvenile's demoralization is inadequately low in its interference factor with regard to the level of their demoralization and weight of the misdeed. Measures such as a reprimand or responsible parental supervision are often ineffective, do not form a stimulus for a change in a juvenile's behaviour or way of acting, and the process of demoralization of an underage continues. As shown by research, ${ }^{32}$ in most cases the educational measure applied in the form of a reprimand or responsible supervision of a parent or guardian, and only later of a court-appointed probation officer, does not lead to a change in the juvenile's way of acting or does not stop the progress of their demoralization. On the contrary, the ineffective reaction of the state made it necessary to adjudicate a corrective measure against them in the future. In order to counteract the progress of the process of demoralization, in many cases it would be advisable to appoint a probation officer much earlier, or send the juvenile to a probation centre where multifaceted work is carried out with the socially unadjusted subject and - very importantly - with their family.

A supervised person tends to equate their court-appointed guardian with the institution of the court, which gives them some authority and opportunity to influence their juvenile subject in a corrective and motivating dimension. In their work, they support them in taking decisions on the direction of their further life path (studies, work) and acting in line with the law and norms of social coexistence. They assist the juvenile by searching institutions, non-governmental organizations or natural persons that can support them in solving various problems and life adversities (e.g. a therapy, treatment, work skills

4. Appointing a youth organization or another social organization, work place or a trustworthy person to supervise and give a guarantee of a juvenile's behaviour;

5. Appointing a probation officer for supervision;

6. Referring one to a probation centre, as well as to social organizations or institutions dedicated to working with the juvenile on the educational, therapeutic or training level, after consulting such an organization or institution beforehand;

7. Adjudicating a driving ban;

8. Adjudicating a forfeiture of property one is in possession of due to a punishable act committed;

9. Adjudicating a placement in a youth educational centre or a professional foster family who was trained to supervise a juvenile.

${ }^{32}$ Research conducted in 2005-2007 on a group of 138 youth from youth detention centres dealt with factors that influence the course of the process of their social readaptation. Among others, they showed that the educational measures previously applied to the research subjects did not bring the expected results in the form of the process of a juvenile's demoralization being curbed. As many as $97.1 \%$ of the subjects who were finally sent to a youth detention centre had been previously submitted to various educational measurep. J. Rajewska de Mezer, Wsparcie instytucjonalne readaptacji społecznej wychowanków zakładów poprawczych, Studia Edukacyjne, 2009, 10, p. 161. 
development etc.). Depending on the type of the problem or need diagnosed, the guardian can serve a control, therapeutic, preventive or aiding function. ${ }^{33}$ They should be able to keep balance among those functions. At each stage of their work with their subject, a court-appointed guardian should seek consensus, agreement or at least compromise between the expectations of justice, and the capabilities and resources of the subject. ${ }^{34}$

A probation officer's supervision is carried out above all using the casework method. It is underlined that this method is particularly valuable when working with the youth who are socially maladjusted, often deprived of individual contacts of educational character in their previous life experience..$^{35}$ Apart from the casework method, group work methods are also used when working with a juvenile and their family. These are based on aiming at stimulating and preserving an individual's energy through the influence of a group and adjusting them to live their life in the society in a better way by showing the necessity and nature of looking after other members of the community or group, too. ${ }^{36}$ The network method is also important in a guardian's work. It is the so-called environmental method which is based on the assumption of working with the child's parents or guardians (their so-called pedagogization); it is of preventive, supportive and corrective character, and protects the child from being isolated from their family in case it is necessary to place them in a resocialization institution. ${ }^{37}$

In their work with a juvenile and their family, guardians, psychotherapists, social workers and pedagogues all use the method of motivating dialogue authored by William R. Miller and Stephen Rollnick. It is based on cooperation and oriented on the target which consists in the way of communicating and paying special attention to the language of change. It aims at strengthening personal motivation and committing oneself to achieving a specific objective by uncovering and analysing a given person's own motives to undergo a change in an atmosphere of acceptance and compassion. ${ }^{38}$ Motivating an

${ }^{33}$ T. Jedynak, K. Stasiak (red.), Zarys metodyki kuratora sadowego, Warszawa 2014, p. 6. and n.

${ }^{34}$ A. Węgliński, Zasoby osobiste $i$ kompetencje zawodowe kuratorów sądowych niezbędne w pracy $z$ osoba dozorowana z problemem alkoholowym, Lubelski Rocznik Pedagogiczny, 2013, XXXII, p. 344. cyt za: J. Rajewska de Mezer, H. Karaszewska, E. Silecka, Pedagogical and legal activities taken in Poland towards people addicted to alcohol (in print).

35 Z. Ostrihańska, A. Greczuszkin, Praca z indywidualnym przypadkiem w nadzorze rodzinnego kuratora sądowego, Lublin 2005, p. 41.

${ }^{36}$ M. Porembska, Rola i zadania kuratora sądowego ds. rodzinnych i nieletnich w pracy $z$ dzieckiem, młodzieża, rodzina, [w:] Profilaktyka i resocjalizacja. Od dysfunkcji do funkcjonalności, Eds. K. Marzec-Holka, T. Głowik, E. Bilska, H. Iwanicki, Warszawa 2012, p. 99-100.

${ }^{37}$ Ibidem, p. 100.

${ }^{38}$ Szerzej R.W. Miller, S. Rollnick, Dialog motywujący. Jak pomóc ludziom w zmianie, Kraków 2014; J.M. Jaraczewska, M. Adamczyk-Zientara (Eds.), Dialog motywujacy. Praca z osobami uzależnionymi behawioralnie, Warszawa 2015. 
underage person to act according to legal and social norms, comply with the schooling obligation, avoid alcohol and substance abuse, build appropriate peer relations and participate in shaping positive atmosphere at home is a considerable challenge for a guardian who supervises them.

A number of problems have at their genesis a juvenile's inadequate relations with their parents as a consequence of the dysfunctional character of their family environment. Many families of a juvenile guardian's subjects face problems that disrupt their normal functioning, e.g. various types of addictions, violence (physical, mental, sometimes sexual), aggressive relations between household members, negligence (as far as satisfying one's basic physical and emotional needs), conflicts resulting from multiple reconstructions of the family and appearance of new life partners of their parents who represent different educational styles and attitudes towards their couple's children. The patterns of social roles, behaviours and reactions that are transmitted to children in dysfunctional families in the process of socialization are often at variance with the socially accepted norms. The family is an elementary socializing environment for the human. In the process of socialization, roles assigned to an individual are assimilated, channelled and internalized, and then modified when used creatively in new groups, which is so crucial for the social life of the human. ${ }^{39}$ Through the process of socialization, " (...) the individual is introduced to the way of life of their group and wider society by learning the rules and ideas included in the culture", ${ }^{40}$ acquires the features of a social person, shapes the competences that make it possible for them to function and put down roots in the structure of a given social system and identify with it, i.e. their expected and accepted social participation. ${ }^{41}$ In the process of primary socialization, children often adopt socially undesired patterns through imitation, one of its mechanisms, in the intergenerational transmission belt. Many times, these patterns lead the child to come into conflict with the norms that are in effect in the society.

Through socialization mechanisms that are based on social control, influence of the so-called significant others or internal reinforcement, an individual "(...) learns the basics of interpersonal relations, gets to know the norms

39 W. Ambrozik, Readaptacja społeczna i reorganizacja środowisk lokalnych jako warunek skuteczności oddziaływań resocjalizacyjnych, [in:] Resocjalizacja. Teoria i praktyka pedagogiczna, t. 2, Eds. B. Urban, J.M. Stanik, Warszawa 2007, p. 183.

40 P. Sztompka, Socjologia. Analiza społeczeństwa, Kraków 2003, p. 286-287.

41 J. Modrzewski, Konformizm i dewiacja w doświadczeniu socjalizacyjnym jednostek $i$ w ich społecznej kwalifikacji, [in:] Socjalizacja dysocjacyjna w doświadczeniu indywidualnym i społecznym. Inspiracje teoretyczne i próby pedagogicznych ingerencji, Eds. A. Matysiak-Błaszczyk, J. Modrzewski, Poznań - Kalisz 2012, p. 24. 
of conduct and values, acquires new skills and shapes their identity". ${ }^{42}$ This is why it is so crucial for the guardian to cooperate also with the juvenile's family, support it in the educational process, help it to work out rules of coexistence with the underage person, cooperate in controlling the juvenile with respect to how they fill out the duties that the family court imposed on them (e.g. complying with the schooling obligation, refraining from spending time in some specific environments). By carrying out both the aiding and supervising functions, a guardian can act as an advisor if it is necessary to support a family in solving a problem related to work, treatment or therapy of the juvenile or their family members. In order to achieve the assumed resocialization and educational aims, court-appointed guardians work not only with the juvenile and their family, but also with the entire environment that their subject lives in by getting engaged in various projects and programmes dedicated to the subjects and focused on the widely understood social prevention. ${ }^{43}$ What determines the effectiveness of a guardian's work is their ability to have a good cooperation with the family, create the right atmosphere for cooperation, use their theoretical and practical knowledge on the topics related to resocializing the juvenile. ${ }^{44}$

One of the forms of educational interactions with a juvenile provided for in the law on juvenile delinquency proceedings also consists in placing the underage person in a youth educational centre or a professional foster family that was trained to supervise the underage. What is characteristic of these centres is that the subject is placed away from their family and submitted to resocialization activities as part of foster care of family or institutional nature. Apart from a juvenile's considerable level of demoralization, the decision to apply the above-mentioned measure is also influenced by diagnosing the juvenile's family situation as unfavourable for a positive course of the process of resocialization, lack of constructive support from the juvenile's family, parental ineptitude or lack of cooperation with the court who supervises the juvenile with a guardian, or with their school. Above all, this measure is focused on educational work with the underage, and its features mean that there is no simultaneous work between the entity that carries out foster care with their subject's family, as is the case when both the individual and their family are interacted with by the court-appointed guardian who operates in the life

${ }^{42}$ C. Kurkowski, "Socjalizacja” w rodzinie z przemoca - droga ku przemocy, [in:] Pedagogika społeczna wobec problemów wspótczesnej rodziny. Polska pedagogika społeczna na początku XXI wieku, Eds. M. Ciczkowska-Giedziun, E. Kantowicz, Toruń 2010, p. 239.

${ }^{43}$ A. Janus-Dębska, Dylematy w pracy kuratora sądowego w świetle badań własnych, cz. II, Probacja, 2016, IV, p. 98.

${ }^{44}$ A. Strumińska, Czynniki warunkujące skuteczność pracy kuratora sądowego, [in:] Profilaktyka i resocjalizacja. Od dysfunkcji do funkcjonalności, Eds. K. Marzec-Holka, T. Głowik, E. Bilska, H. Iwanicki, Warszawa 2012, p. 120-141. 
environment of the subject they supervise and their family. It is also interesting to notice that emotional bonds between a juvenile placed in a centre and their family members may loosen, which will have significant consequences that will be a barrier for the process of social readaptation of a juvenile who leaves their foster care institution.

The law on juvenile delinquency proceedings gives the family court some flexibility in using the previously adjudicated measures. The court can change or overrule educational measures if justified by educational factors. ${ }^{45} \mathrm{~A}$ modification of the interaction depends on the situation diagnosed, changes observed in the juvenile's conduct and progress (or its lack) in their resocialization process. Family and juvenile court adjudications on applying specific measures should be based on expert pedagogues' and psychologists' opinions developed following a thorough analysis of a juvenile's situation, their demoralization level, willingness to cooperate in the educational process, state of their awareness, as well as taking into account the state of their educational environment (family), their educational potential, readiness to co-work and accept help in the educational process, method and scope of carrying out socially defined functions. In some cases, an analysis of the above-mentioned circumstances will justify placing the juvenile away from their family using various forms of foster care; in others, it will be possible to apply measures of influencing the individual who will remain in their current family environment, and, as a result, the environment itself.

On the other hand, a corrective measure is a measure in-between educational measures and a sanction provided for in penal law. The family court can adjudicate a juvenile who committed a punishable act to be placed in a youth detention centre, ${ }^{46}$ as well as when it is justified by a high level of demoralization of the underage person, circumstances and character of their misdeed, and when other educational measures turned out to be ineffective or do not portend the juvenile's resocialization. ${ }^{47}$ Based on the above, this measure can be viewed as the most severe form of the state's reaction to a juvenile with no criminal liability committing a punishable act. It is adjudicated after the family and juvenile court has carried out corrective proceedings based on penal procedures. A corrective measure can be carried out in the types of youth detention centres defined by law. ${ }^{48}$

${ }^{45}$ P. Górecki, Postępowanie poprawcze, p. 61.

${ }_{46}$ According to article $1 \S 2$ point 2 letter a of the law on juvenile delinquency proceedings of 26 October 1982 (DzU z 2017, poz. 773 ze zm.), who committed a crime or a tax offence.

${ }^{47}$ Art.10 ustawy o postępowaniu w sprawach nieletnich z 26 paźdniernika 1982 r. (DzU z 2017, poz. 773 ze zm.).

48 According to $\$ 3$ of the Ministry of Justice order of 17 October 2001 on youth detention centres and juvenile shelters (DzU z 2017, poz. 487), detention centres can be divided into: 1) resocialization centres: a) open - youth centres for social adaptation, b) half-open, c) closed, 
According to the provisions of the law on juvenile delinquency proceedings, the aims to be achieved by applying a corrective measure are of significant social importance and incredibly lofty, yet difficult to reach, as proved by researchers dealing with the effectiveness of resocialization activities among the juvenile. As phrased in the law, using a corrective measure is supposed to lead to

educating a juvenile to become an aware and honest citizen, (...) and should above all be aimed at a comprehensive development of their personality and skills, and shaping and reinforcing the socially desired attitude and sense of responsibility in them, so that they are adequately prepared for socially useful work. ${ }^{49}$

These aims seem to be uneasy to achieve in the process of primary socialization of a child who was not diagnosed with social maladjustment. Consequently, achieving them with respect to those who were submitted to a corrective measure due to their significant level of demoralization and punishable act committed typically poses a considerable challenge. A situation where the juvenile does not return to crime and acts according to legal norms, i.e. achieving the so-called resocialization minima, would be a satisfying result of those interactions (as indicated by H.Machel, a researcher into the aims of penitentiary resocialization ${ }^{50}$ ).

A youth detention centre is a resocialization institution of a closed character that has a specific organizational structure and provides its detainees with social, pedagogical, psychological and medical care. As part of the corrective measure being completed, resocialization interactions are carried out with the aim of achieving a change in a juvenile's former attitudes, beliefs, mindset and habits that are at variance with social and legal norms. ${ }^{51}$ The juvenile is submitted to compulsory education; they are educated both in general and professional terms. They are provided with an opportunity to achieve competences that will make it easier for them to function in the open environment. Psychological and pedagogical staff also works with juveniles' families in or-

d) of intensified surveillance; and 2) resocialization and revalidation centres, and 3) resocialization and therapeutic centres.

${ }^{49}$ Art. 65 u.p.n.

${ }^{50} \mathrm{H}$. Machel indicated two aims of penitentiary resocialization: the minimum aim (when released, the detainee would function in society without breaking legal norms) and the maximum aim (when released from a penal facility, the detainee would not only refrain from breaking legal norms, but they would also take up and fulfil social roles in a constructive way, which would allow them to take active part in social life: H. Machel, Więzienie jako instytucja karna i resocjalizacyjna, Gdańsk 2003, p. 21 and n.

${ }^{51} \mathrm{H}$. Iwanicki, Wspótczesne problemy w resocjalizacji nieletnich przebywających $w$ zakładach poprawczych, [in:] Profilaktyka i resocjalizacja. Od dysfunkcji do funkcjonalności, Eds. K. Marzec-Holka, T. Głowik, E. Bilska, H. Iwanicki, Warszawa 2012, p. 40-41. 
der for the juvenile to establish and maintain contact with their family, thus attempting to counteract the dissolution of emotional bonds that are crucial for the process of social readaptation of the detainee. By accompanying their subjects on some of their passes or contacting their families when the juvenile is temporarily released home (a pass, staying away from the detention centre as provided for in article 90 u.p.n.), they take up activities also directed at the juvenile's family environment.

It is worth noting that the rule of determining the penalty duration, in this case the detention centre placement, that is characteristic of penal law does not apply among the rules of juvenile delinquency proceedings. An educational or corrective measure is carried out till the expected level of the detainee's resocialization is achieved.$^{52}$ It is thus not adjudicated for a specific period of time (years or months), as is the case in the context of a penalty. The time limit for carrying out a corrective measure defined by law is reaching 21 years of age by the detainee. Irrespective of the level of the juvenile's resocialization and guarantee of them respecting legal or social norms, the circumstance of them reaching the specific age (21) leads to the executive proceedings towards them being obligatorily dismissed. What follows, institutional interactions are also discontinued, despite the fact that, for example, there is no positive effect as far as the juvenile's resocialization is concerned, or there is no change in their destructive and antagonistic functioning with regard to the socially expected norms. Regulations in the law on juvenile delinquency proceedings also provide for an option of conditional release from the youth detention centre before the detainee is 21 . When adjudicating in this respect, the family court takes into account the premise that the progress in the juvenile detainee's education at the facility makes it possible to assume that they will abide by the legal order and rules of social coexistence once released. ${ }^{53}$ In order to be able to be adjudicated a conditional release from a youth detention centre, a juvenile should have spent at least six months there. ${ }^{54}$

A juvenile conditionally released from a youth detention centre is under the surveillance of the court that appoints a family guardian to supervise them

${ }^{52}$ The issue of juvenile resocialization at youth detention centres was taken up by A. Krukowski in 1980s. Based on research, he noticed that the rule of relative definition of the duration of a corrective measure itself serves as a factor that makes it possible to individualise the time frames educational interactions of the detention centre according to the needs of a given detainee and as a strong stimulus for the juvenile to cooperate in the process of resocialization: A. Krukowski, Resocjalizacja w zakładzie poprawczym w świetle przepisów prawa, [in:] Problemy resocjalizacji nieletnich w zakładach poprawczych, Materiały sympozjum naukowego w Chojnicach, Ed. W. Patulski, Ministerstwo Sprawiedliwości, Warszawa 1986.

${ }_{53}$ Art. 86. \$1 ustawy o postępowaniu w sprawach nieletnich.

54 The court can include the time spent by the juvenile at a juvenile shelter into the period spent at a youth detention centre required for the conditional release (article $86 \S 2$ upn). 
for a trial period (of between one and three years) as part of their support. In such cases, the scope of a guardian's activities is the same as the activities taken up by a family guardian if they are appointed to supervise a juvenile as a separate educational measure. The activities of a guardian in case of supervising a conditionally released juvenile are directed at supporting them in the process of their social readaptation that consists in readjusting them to independent life and fulfilling social roles which will comply with social requirements..$^{55}$

When working with a juvenile and applying the methods previously mentioned in this paper, a guardian motivates them to take up the effort to continue learning out of the facility (helps them to find a school or specialist courses of a given profile), and supports them in their job search or formalities linked to being offered a job. As one of the factors influencing the course of social readaptation, entering the professional role makes it possible to satisfy an individual's material needs, is important for shaping one's self-esteem and professional usefulness and petrifies one's stable social situation. Another form of helping one to be socially included is for a juvenile who finds it difficult to deal with the change of their situation (leaving the facility and returning to life in the society) to be directed to specialists (psychologists, psychiatrists, doctors of other specialisations) to participate in therapy and receive psychological help or treatment.

Apart from the guardian, also the staff of the youth detention centre where the juvenile prepares to be released can provide their charge with information crucial for them to continue learning, find employment and receive material help that people leaving foster care institutions are entitled to, or inform them about the features of total institutions. The law on welfare makes it possible to provide a person of legal age who leaves a detention centre with help aimed at their life independence and integration with the environment through social work, as well as financial help for them to live independently and continue learning, material help to obtain adequate housing conditions, including protected housing, and employment, and to relocate. ${ }^{56}$

Some facilities organise workshops for the juvenile where they discuss legal topics related to the situation of an underage who leaves a detention centre. Issues that are touched upon include, among others, those related to welfare benefits of financial and non-financial character, conditions necessary to acquire them, topics related to family law (e.g. establishing paternity, parental authority, child benefit), labour law and social security.

\footnotetext{
55 W. Ambozik, Readaptacja społeczna i reorganizacja środowisk lokalnych, p. 190.

${ }^{56}$ Art.88 ustawy z 12 marca 2004 r. o pomocy społecznej (DzU z 2017, poz. 1769 ze zm.).
} 
Carrying out educational or corrective measures adjudicated for a juvenile in order for the juvenile to be able to function correctly in their environment in line with social expectations related to them entering social roles, requires multifaceted support provided to them and their families by various entities who create the system of resocialization and aiding interactions. What I mean here are family courts, court guardians who work in them, staff of youth educational centres and youth detention centres, social workers and family assistants who provide support to families based on the law on welfare and the law on supporting the family and system of foster care, psychologists and therapists working in supporting institutions that specialise in treating diverse issues of an individual and family functioning, lawyers who provide specialist legal counselling, education staff, teachers and tutors (often depending on their reactions to a juvenile's conduct and their way of making parents cooperate with the school, formal actions are taken with the aim to stop the process of social maladjustment of a juvenile).

Aiding and corrective activities, as well as those that support and activate an individual and their environment of origin (that they are supposed to return to after all when the adjudicated educational or corrective measure is carried out), have to be based on cooperation between the entities that provide them, individual approach to each case, awareness of the specific qualities of the subject of interactions who often is a juvenile of still limited awareness of the meaning of their deed, still in the process of being shaped as a social individual.

The activities discussed should not be of penal or sanctional character; they should motivate the juvenile to act in line with social and legal norms, activate them to enter assigned social roles, and at the same time respect their right to self-determination and free choice. Those who provide activities related to resocialization, aid or activating support should apply the principle of subsidiarity, manifested in subsidiary support for the individual who learns to take responsibility for their actions or refrain from certain spheres of life. They should also be aware of the need to change the forms of control or support at the right time to interfere less and allow the subject of their interactions to shape their self-awareness, responsibility and independence.

The process of resocializing a juvenile is a long-lasting and complicated one. Its effectiveness depends on many intertwining factors present at different stages of life; some of them foster its course, while others interfere with it. The desired course of the process of resocialization, carried out based on the measures provided for by law, supported by the entities mentioned in this paper, makes it possible for an individual to readapt and be actively present in the society. 


\section{BIBLIOGRAPHY}

Ambozik W., Readaptacja społeczna i reorganizacja środowisk lokalnych jako warunek skuteczności oddziaływań resocjalizacyjnych, [in:] Resocjalizacja. Teoria i praktyka pedagogiczna, t. 2, Eds. B. Urban, J.M. Stanik, Warszawa 2007.

Bee H., Psychologia rozwoju człowieka, Poznań 2004.

Bojarski T., Podstawowe założenia traktowania nieletnich w świetle ustawy o postępowaniu w sprawach nieletnich oraz aktualnych potrzeb, [in:] Teoretyczne i praktyczne problemy stosowania ustawy o postępowaniu w sprawach nieletnich, Eds. T. Bojarski, E. Skrętowicz, Lublin 2001.

Gardocki L., Czy karać nieletnich? Palestra, 1994, 38/11 (443).

Gardocki L., Prawo karne, Warszawa 2017.

Górecki P., Postępowanie poprawcze w sprawach nieletnich, Sopot 1998.

Gromek K., Wprowadzenie do ustawy o postepowaniu w sprawach nieletnich po nowelizacji z dnia 15 września 2000 r., Warszawa 2001.

Grześkowiak A., Postępowanie w sprawach nieletnich (polskie prawo nieletnich), Torun 1986.

Hałas R.G., Podmiot przestępstwa, [in:] Prawo karne, Eds. A. Grześkowiak, K. Wiak, F. Ciepły, M. Gałązka, R.G. Hałas, S. Hypś, D. Szeleszczuk, Warszawa 2017.

Iwanicki H., Wspótczesne problemy w resocjalizacji nieletnich przebywajacych w zakładach poprawczych, [in:] Profilaktyka i resocjalizacja. Od dysfunkcji do funkcjonalności, Eds. K. Marzec-Holka, T. Głowik, E. Bilska, H. Iwanicki, Warszawa 2012.

Janus-Dębska A., Dylematy w pracy kuratora sądowego w świetle badań własnych, cz. II, Probacja, 2016, IV.

Jaraczewska J.M., Adamczyk-Zientara M. (Ed.), Dialog motywujący. Praca z osobami uzależnionymi behawioralnie, Warszawa 2015.

Jedynak T., Stasiak K. (Eds.), Zarys metodyki kuratora sądowego, Warszawa 2014.

Kuć M., Prawne podstawy resocjalizacji, Warszawa 2011.

Krukowski A., Resocjalizacja w zakładzie poprawczym w świetle przepisów prawa, [in:] Problemy resocjalizacji nieletnich $w$ zakładach poprawczych, Materiały sympozjum naukowego w Chojnicach, Ed. W. Patulski, Ministerstwo Sprawiedliwości, Warszawa 1986.

Kurkowski C., "Socjalizacja” w rodzinie z przemoca - droga ku przemocy, [in:] Pedagogika spoteczna wobec problemów wspótczesnej rodziny. Polska pedagogika społeczna na początku XXI wieku, Eds. M. Ciczkowska-Giedziun, E. Kantowicz, Torun 2010.

Lewicka-Zelent A., Wspólna przestrzeń dla resocjalizacji inkluzyjnej i mediacji, Probacja, 2016, IV.

Machel H., Więzienie jako instytucja karna i resocjalizacyjna, Gdańsk 2003.

Makarewicz J., Kodeks karny z komentarzem, Lwów 1932.

Meier B.D., Sprawiedliwość naprawcza - zarys koncepcji, [in:] Mediacja. Nieletni przestępcy i ich ofiary, Eds. B. Czarnecka-Dzialuk, D. Wókcik, Warszawa 1999.

Miller R.W., Rollnick S., Dialog motywujący. Jak pomóc ludziom w zmianie, Kraków 2014.

Modrzewski J., Konformizm i dewiacja $w$ doświadczeniu socjalizacyjnym jednostek $i w$ ich społecznej kwalifikacji, [in:] Socjalizacja dysocjacyjna w doświadczeniu indywidualnym i społecznym. Inspiracje teoretyczne i próby pedagogicznych ingerencji, Eds. A. Matysiak-Błaszczyk, J. Modrzewski, Poznań - Kalisz 2012.

Ostrihańska Z., Greczuszkin A., Praca z indywidualnym przypadkiem w nadzorze rodzinnego kuratora sądowego, Lublin 2005.

Piaget J., Studia z psychologii dziecka, Warszawa 1966.

Piaget J., Inhelder B., Psychologia dziecka, Wrocław 1993.

Peiper L., Komentarz do Kodeksu Karnego, Kraków 1932. 
Porembska M., Rola i zadania kuratora sądowego ds. rodzinnych i nieletnich w pracy z dzieckiem, młodzieża, rodzina, [in:] Profilaktyka i resocjalizacja. Od dysfunkcji do funkcjonalności, Eds. K. Marzec-Holka, T. Głowik, E. Bilska, H. Iwanicki, Warszawa 2012.

Rajewska de Mezer J., Wsparcie instytucjonalne readaptacji społecznej wychowanków zakładów poprawczych, Studia Edukacyjne, 2009, 10.

Rajewska de Mezer J., Karaszewska H., Silecka E., Pedagogical and legal activities taken in Poland towards people addicted to alcohol (in print).

Rozporządzenia Ministra Sprawiedliwości z 17 paźdniernika 2001 r. w sprawie zakładów poprawczych i schronisk dla nieletnich (DzU z 2017, poz. 487).

Ustawa z 6 czerwca 1997 Kodeks karny (DzU z 2016, poz. 1137 ze zm.).

Ustawa z 6 czerwca 1997 Kodeks karny wykonawczy (DzU z 2017, poz. 665 ze zm.).

Ustawa z 12 marca 2004 r. o pomocy społecznej (DzU z 2017, poz. 1769 ze zm.).

Schaffer H.R., Psychologia dziecka, Warszawa 2009.

Stańdo-Kawecka B., Prawne podstawy resocjalizacji, Kraków 2000.

Strelau J., Doliński D. (red.), Psychologia: podręcznik akademicki, t. 2, Gdańsk 2008.

Strumińska A., Czynniki warunkujące skuteczność pracy kuratora sądowego, [in:] Profilaktyka i resocjalizacja. Od dysfunkcji do funkcjonalności, Eds. K. Marzec-Holka, T. Głowik, E. Bilska, H. Iwanicki, Warszawa 2012.

Sztompka P., Socjologia. Analiza społeczeństwa, Kraków 2003.

Węgliński A., Zasoby osobiste i kompetencje zawodowe kuratorów sądowych niezbędne w pracy z osoba dozorowana z problemem alkoholowym, Lubelski Rocznik Pedagogiczny, 2013, XXXII.

Wolter W., Zarys systemu prawa karnego, t. 2, Kraków 1933. 